Letter to the Editor

\title{
Comment on Sticky Platelet Syndrome
}

\author{
Guillermo J. Ruiz-Arguelles, MD, FRCP (Glasg), MACP ${ }^{1}$ \\ ${ }^{1}$ Centro de Hematologia y Medicina Interna, Clinica Ruiz, Puebla, \\ PUE, Mexico \\ Semin Thromb Hemost 2014;40:273.
}

Address for correspondence Guillermo J. Ruiz-Arguelles, MD, FRCP (Glasg), MACP, Centro de Hematologia y Medicina Interna, Clinica Ruiz, 8B Sur 3710, 72530 Puebla, PUE, Mexico (e-mail: gruiz1@clinicaruiz.com).

I read with special interest the article on sticky platelet syndrome (SPS) by Kubisz et al. ${ }^{1}$ Particularly outstanding is that the condition, forgotten for some time and ignored by many researchers, has deserved a special place in the current thrombosis field and seems to be progressively recognized. We have been interested in the SPS for many years and published many observations. In the specific topic of the treatment of the condition, we recently published a prospective study conducted in 55 consecutive patients with a history of thrombosis and SPS phenotype, studied before and after treatment with aspirin and/or clopidogrel. Patients were followed for 1 to 129 months, with a median of 13 months. A total of 40 patients received aspirin, 13 aspirin + clopidogrel, and 2 only clopidogrel. The platelet aggregation response to adenosine diphosphate and epinephrine significantly diminished after treatment and only two individuals developed another thrombosis, 52 and 129 months after starting therapy; interestingly, these two episodes were located in the retinal central artery and neither individual was identified to have any additional associated thrombophilic conditions despite a full laboratory workup, which included antiphospholipid antibodies, lupus anticoagulant, protein C, protein S, antithrombin III, factor $\mathrm{V}$ Leiden mutation, prothrombin gene

mutation, and MTHFR gene mutation. The freedom from rethrombosis rate of these SPS patients was $96.4 \%$ at 129 months, thus proving that by using antiplatelet drugs the platelet hyperreactivity of these patients with the SPS phenotype was reverted and that this translated into a substantial decrease of the rethrombosis rate. ${ }^{2}$ To our knowledge, this is the only prospective study analyzing both the in vivo and in vitro effects of antiplatelet drugs in the SPS; this information should be added to that presented by Kubisz et al in their excellent review, confirming their observation that antiplatelet drugs are efficient in both treatment and prophylaxis of thromboembolism in individuals with SPS. ${ }^{1}$

\section{References}

1 Kubisz P, Stasko J, Holly P. Sticky platelet syndrome. Semin Thromb Hemost 2013;39(6):674-683

2 Velázquez-Sánchez-de-Cima S, Zamora-Ortiz G, Hernández-Reyes $\mathrm{J}$, et al. Primary thrombophilia in Mexico X: a prospective study of the treatment of the sticky platelet syndrome (e-pub ahead of print). Clin Appl Thromb Hemost 2013; doi: 10.1177/ 1076029613501543

published online February 5, 2014
Issue Theme Quality in Hemostasis and Thrombosis, Part III; Guest Editors, Emmanuel J. Favaloro, PhD, FFSc (RCPA), Giuseppe Lippi, MD, and Mario Plebani, MD.
Copyright $\odot 2014$ by Thieme Medical Publishers, Inc., 333 Seventh Avenue, New York, NY 10001, USA. Tel: +1(212) 584-4662.
DOI http://dx.doi.org/ 10.1055/s-0034-1367473. ISSN 0094-6176. 